\title{
Gisela Swetlana Ortriwano
}

\section{Rádio: interatividade entre rosas e espinhos*}

(1) BRECHT, Bertolt "Teoria dela radio (1927-1932)". In: BASSETS, Luís(ed.). De las ondas rojas a las radios libres. Barcelona, Gustavo Gili, 1981, pp. 48-61.

(2) Em "O Jomalismo na Teoria do Rádio" fizemos uma primeira abordagem sobre o assunto. In: ORTRIWANO, Gisela Swetlana.

Os (des)caminhos do radiojornalismo. São Paulo, ECAUSP, 1990, tese (doutorado), pp. 08-33.

(3) BASSETS, Luís. Op. Cit, pp. 48-49 (nota de rodapé).

(4) BRECHT, Bertolt "Teoria dela Radio(1927-1932)". Op. at, pp. 56-57(grifos nossos).

\section{Gisela Swetlana Ortriwano é} Professora Doutora junto ao Departamento de Jornalismo e Editoração da ECA/USP. É autora, entre outras obras, do livro $A$ informação no rádio - os grupos de poder e a determinação de conteúdos. Ed. Summus, São Paulo, 1993, $3^{\circ}$ ed.

\section{* Artigo originalmente publicado na Revista Novos Olharesn. 02, de 1998 eaqui integralmente reproduzido em homenagemasua autora, co-fundadora do Grupo de Estudos sobre Práticas de Recepção e da Revista Novos Olhares.}

\begin{abstract}
"Um homem que tenha algo a dizer e não encontre ouvintes, está em má situação. Mas estão em pior situação ainda os ouvintes que não encontrem quem tenha algo a dizer-lhes. " - Bertolt Brecht
\end{abstract}

1. Em busca de um destino para 0 rádio

Bertolt Brecht (1898-1956), poeta e ensaísta alemão, não pode deixar de ser citado quando se pretende discutir rádio. Sob o título Teoria do Rádio ${ }^{1}$ estão reunidos cinco textos dispersos, três dos quais divulgados na época em que foram escritos (entre 1927 e 1932), em publicações de pequena circulação. Os outros dois permaneceram inéditos, tendo sido os originais encontrados em cadernos manuscritos após a morte do autor. $^{2}$

Impossível pretender discutir a interatividade no rádio sem considerar suas reflexões sobre o primeiro meio de comunicação eletrônico da história que, com o passar do tempo, tornam-se cada vez mais atuais. Para Lluís Bassets, "nestes escritos [Brecht] mostra-se como uma das mentes de maior clarividência de nosso século no terreno dos meios de comunicação". ${ }^{3}$ Brecht imagina o rádio com dupla mãode-direção, alertando que a hoje denominada interatividade é um anseio antigo do ouvinte. A questão é tratada muito mais sob a ótica da política, da organização democrática da sociedade e do relacionamento entre cidadãos, do que sobre a exclusividade de uma ou outra tecnologia de informação. Os textos contrariam uma visão desenvolvimentista e lembram que o rádio, antes de ser um meio de comunicação de massa, era um meio interativo de comunicação, que se viu limitado em sua capacidade bidirecional à medida em que se constituía o sistema econômico de sua exploração. E poderia ser um excelente meio de entretenimento, dando suporte a diferentes manifestações culturais.

Muitas das potencialidades antevistas - ou sonhadas - por Brecht só agora, incorporando os novos recursos tecnológicos, começam a ser exploradas. "O rádio seria o mais fabuloso meio de comunicação imaginável na vida pública, constituiria um fantástico sistema de canalização, se fosse capaz, não apenas de emitir, mas também de receber. O ouvinte não deveria apenas ouvir, mas também falar: Não isolar-se, mas ficar em comunicação com o rádio. A radiodifusão deveria afastar-se das fontes oficiais de abastecimento e transformar os ouvintes nos grandes abastecedores."

A preocupação de Brecht com as duas mãos-de-direção possíveis ao rádio é explícita em seus escritos. Mas até hoje, a interatividade continua controlada: a participação do ouvinte é limitada a pequenas intervenções, seja por telefone, seja ao vivo. Se o gênero é o jornalismo, predominam as reclamações quanto aos serviços em geral, o testemunho sobre algum acontecimen- 
to, via telefone, fax, cartas, ou enquete/ povo-fala conduzido por um repórter; emitir opiniões, a partir de somente respondendo a perguntas específicas, com respostas curtas e, pretensamente, objetivas. Se nos programas dos chamados comunicadores, a participação inclui responder à perguntas, geralmente envolvendo prêmios, pedidos e oferecimentos de músicas os célebres a pedidos, depoimentos sobre as mazelas do dia-a-dia, explorando ao máximo a emocional idademente atual e, em diferentes momentos de cada situação como as dramatizações de cartas, de casos programas policiais etc. Com a introdução das tecnologias baseadas na informática, novas possibilidades de interação surgiram, como o correio eletrônico, o e-mail. Da mesma forma, o controle é sempre do emissor, nunca do receptor.

"Quando formulou sua teoria, Bertolt Brecht identificava um rádio que, a par das naturais deficiências técnicas, só não se completava artística, social e politicamente devido à limitação do elemento humano envolvido no processo. Se vivesse na atualidade, além de ver confirmados muitos de seus prognósticos e atendidas muitas de suas recomendações, ele iria constatar que acertara, também, ao condicionar o uso eficiente do rádio à visão de seus dirigentes. Diante da atual parafernália técnica, a cada dia enriquecida com novos e mais eficientes recursos, ele certamente iria sentenciar que tudo isso é inútil se não existir uma conexão ouvinte/rádio tão efetiva quanto a já existente rádio/ouvinte." 5 Mario Fanucchi completa seu pensamento afirmando que para Brecht, o papel do rádio é o de estar em perfeita sintonia com as aspirações da sociedade, transmitindo/recebendo informações de todos os tipos.

Na prática, o ouvinte, como fonte direta de (re)alimentação do sistema só participa na medida em que atende aos interesses do próprio sistema, nunca para questioná-lo. Por outro lado, como fonte indireta, as expectativas do público-alvo são levadas em consideração não apenas com o objetivo de manter a fidelidade da audiência já conquistada, mas também com o intuito de ampliá-la.

No sistema de exploração comercial da radiodifusão soa ingênua e até utópica a proposta de que toda e qualquer pessoa possa vir a produzir os programas que venha a ouvir. Esta é uma questão que continua extremada história, o assunto tem voltado à tona. No início, pelas emissoras operárias, como veremos a seguir. Em outros momentos, através das experiências de emissoras piratas que reivindicam seu direito ao mercado radiofônico; ou então, são as rádios livres, sob diferentes bandeiras, buscando espaços para as chamadas , minorias. Ou as rádios populares, as rádios cornetas. $\mathrm{E}$, atualmente, a questão é discutida sob a ótica da democratização dos meios de comunicação e dos chamados movimentos populares, engajados na luta pela plena utilização das rádios comunitárias. Não podemos esquecer outra faceta: as emissoras virtuais que conquistam seu espaço na Internet.

Em todo o mundo, não apenas a proliferação de emissoras de rádio tradicionais de pequeno alcance $\mathrm{e}$ objetivos específicos, como também as virtuais, soam como promessas do amplo e irrestrito acesso à informação nesta virada de milênio. Se, por um lado, muitas comunidades já têm sua própria comunicação radiofônica estabelecida, de fato, há anos, com a regulamentação das rádios comunitárias inicia-se uma nova fase que exige uma redefinição para todo o meio radiofônico uma vez que características que pareciam intrínsecas à exploração da radiodifüsão estão mudando. Para citar apenas um dos muitos exemplos, a Rádio Favela FM de Belo Horizonte opera, sem concessão, desde 1981, tendo sido
(5) FANUCCHI, Mario. "O rádio de Bredht setenta anos depois". In: Revista USP, São Paulo, $n^{\circ} 34$, junho/agosto 1997, p. 131 (grifos doautor). 
(6)WAINER, João. "Rádio Favela FM saidos barracos para o mundo". In: Folha de São Paulo/

Ilustrada, 23.07.1998, p. 1. (7) HALE, Julian. La radio como arma política. Barcelona, Gustavo Gili, 1979, p. 11.

(8) DAHL, Peter. "Detrás detu aparato de radio está el enemigo de dasse". In: BASSETS, Luís.

Op. at, p. 19.

(9) MARCONDES FLHO, Oro. 0 discurso sufocado. São Paulo, Loyola, 1982, p. 26.

(10) Ibid., p. 29.
Dedicando-se a prestar serviços para a comunidade, já recebeu vários prêmios internacionais. ${ }^{6}$

Mas nem tudo são flores. Desde suas primeiras experiências de transmissão pública, a utilização do rádio como meio de comunicação suscitou divergências. Sem o domínio pleno das potencialidades do novo meio, várias correntes de pensamento buscavam espaço para implantar suas idéias. O rádio foi, inclusive, considerado por alguns como um perigoso agente de padronização, "o mais poderoso que o mundo já conheceu". "Nas décadas de 1920 e 1930, quando o rádio era ainda uma novidade, foram alegadas pretensões exageradas - especialmente na Alemanha, América do Norte e Inglaterra - no que diz respeito a seu poder para influenciar a mente humana." As divergências - como os espinhos - continuam a existir: o rádio consegue cumprir as duas mãos-dedireção de sua potencialidade interativa?

2. Crise conjuntural $I$ : as rádios operárias

Para pode avaliar as idéias pregadas por Brecht sobre o rádio, é preciso conhecer alguns fatos que formavam o quadro alemão da época em que a radiodifusão engatinhava, em uma Europa politicamente conturbada. "A história do rádio alemão começa com a revolução de 1918-1919. Ainda que fossem necessários mais cinco anos até o estabelecimento de uma 'radiodifusão pública de entretenimento' na Alemanha, a história do rádio teve seu momento culminante em 1918-1919 se considerarmos sua função social e tudo aquilo que os envolvidos queriam e podiam fazer com ele." 8

A República de Weimar instalouse após a queda do Império, a 9 de novembro de 1919. Formada por uma coalizão social-centro-democrata, estava apoiada por uma constituição progressista que estabelecia o sufrágio universal, representação proporcional, sistema parlamentar, defesa das liberdades básicas e direito a trabalho, educação e assistência social. Mas esse governo, num país sem tradições democráticas, era ameaçado pelo caos deixado pela I Guerra e pelas pressões do extremismo reacionário. A crise sócioeconômica fazia parte desse quadro (hiperinflação, desemprego etc.). A 30 de janeiro de 1933, Adolf Hitler foi nomeado chanceler da Alemanha. Imediatamente dissolveu o parlamento, convocou novas eleições e criou o III Reich, abolindo o Estado federativo. Em agosto de 1934 Hitler suprimiu o cargo de presidente e deu a si mesmo o título Führer und Reichskanzler (líder e chanceler do Reich).

Segundo Marcondes Filho, "a miséria da República de Weimar não era somente de caráter conjuntural, com desemprego, inflação, destruição, guerra, mas também e com grande importância de caráter estrutural, com a grande massa de desapossados se amargurando pela perda da segurança econômica e social do passado". ${ }^{9}$ Ele considera que "o desenvolvimento do rádio, ligado às lutas sociais, já se havia iniciado, entretanto, junto com o próprio surgir da República. Na Revolta dos Marinheiros em Kiel (1918), estes usaram o rádio em sua luta, fato que pode ser considerado como o marco do início do 'Movimento do Rádio Operário' na Alemanha". ${ }^{10}$

Nos anos 20 e 30 o rádio era ainda uma novidade fascinante para muitos e a possibilidade dos aparelhos receptores - e até transmissores poderem ser montados pelos próprios ouvintes em muito contribuiu para que o novo meio ganhasse impulso em seu desenvolvimento. "Esse tipo de entretenimento não somente permitia ao trabalhador exercer uma atividade criativa e compensadora para as horas de lazer, ou seja, que lhe proporcionava prazer e possibilidade de desenvolverse pessoalmente, bem como lhe possibilitava, pelo simples fato de 
construir um aparelho de comunicação, ampliar consideravelmente seu interesse pelos assuntos da vida coletiva. A construção de um aparelho de rádio e o prazer de vê-lo em funcionamento, de receber mensagens, produzia nos construtores amadores um sentido de integração na vida coletiva, possibilidade de interferir nela e, em última instância, de atuar politicamente."11

Hale considera que "no movimento de rádios operárias da época de Weimar, o rádio não organizou seus ouvintes: estes organizaram a si próprios". E completa dizendo que "no início, para os membros dos radioclubes operários tratava-se, antes de mais nada, de poder ouvir os novos sons". ${ }^{12}$ Os trabalhadores trocavam entre si esquemas técnicos de montagem (publicados em revistas especializadas que começaram a circular já no início dos anos 20), peças de reposição e desfrutavam em grupo os aparelhos que construíam. A preocupação básica era poder ouvir o novo meio uma vez que o preço do receptor era elevado: construílo era uma forma de satisfazer a esta aspiração. A partir deste envolvimento inicial, foram sendo criadas condições para uma participação explicitamente política. Com os aparelhos que montavam, era possível ouvir inclusive programas do exterior, principalmente as emissões operárias da União Soviética.

A expansão desse aparelho de aproximação das massas não foi livre nem fácil. Para barrar seu avanço, foram criados instrumentos legais que reduzissem o efeito multiplicador - em termos políticos - dessas experiências de comunicação. Em 1924 é baixado um decreto-lei contra os ouvintes clandestinos. Os aparelhos de uso domiciliar foram obrigados a ter licença e o governo passou a usar os chamados interceptores de onda para interferir e prejudicar a recepção das emissões nãooficiais. Essas medidas, ainda de acordo com Marcondes Filho "não acabaram com o espírito de participação no processo comunicativo, ainda que reduzissem bastante o desenvolvimento da construção amadora de rádios. Em 1926, o ARK ('Clube do Rádio Operário'), fundado em 1924 para o desenvolvimento da radiodifusão proletária, criou em toda a República comunidades de ouvintes; através delas ouviam-se e discutiam-se em conjunto as emissões de rádio - p. ex., nas 'Noites Populares' trabalhava-se principalmente com textos de escritores políticos engajados e na 'Hora do Rádio Operário' com emissões de direita da rádio Deutsche Welle - e remetiam-se as críticas às emissoras". ${ }^{13}$ As rádios oficiais apresentavam programas considerados reacionários, distanciados das discussões políticas e sociais da época. $\mathrm{O}$ controle político das emissoras era geralmente exercido diretamente. Houve épocas em que as estações eram obrigadas a ter a presença de censores para controlar o conteúdo dos programas que seriam apresentados. Mas até 1928, a radiodifusão alemã declarava-se neutra. Após esta data surgem as investidas ostensivas para a politização do rádio ao mesmo tempo em que a organização dos ouvintes era cada vez mais intensificada.

"O programa de trabalho de agitação da 'Associação Livre de Rádio Alemão', juntamente com o acirramento das tensões sociais do período, com mobilizações políticas em tomo de todos os principais partidos, por exemplo, lutava por isso procurando organizar os radiouvintes e desencadear ações de massa contra o programa de rádio dominante. Ele organizava as 'Noites de Audiência', instalando alto-falantes e aparelhos de rádio em locais públicos, para que a massa pudesse ouvir e discutir (nas 'comunidades de audiência') os noticiosos das rádios oficiais. Nesses grupos havia setores específicos para mulheres, crianças e escolares."14 A partir de 1930, "lentamente o rádio oficial ia se tomando porta-voz do governo e perdia toda a aparência de
(11)Ibid., p. 29.

(12) HALE, Julian. Op. at..pp. 28-29.

(13) MARCONDES FLHO, Giro. Op.

at, p. 30.

(14) Ibid., p. 39. 
(15) Ibid.,p. 41.

(16) GARCIA CAMARGO, Jimmy. $L$ a radio por dentro e por fuera. Quito, Ciespal, 1980, p. 20. (17) In: HALE, Julian. Op. at, p. 23.

(18) Ibid., p. 24.

(19) Ibid., p. 25.

(20) MARCONDESFIHO, Giro.

Op. at, p. 44.

(21) Trecho do Arquivo da

Deutsches Rundfunk DRA C 736, atado por DAHL, Peter. Op. $a \mathrm{at}, p .26$.

(22) BRECHT, Bertolt Op. at, p. 56. imparcialidade que o caracterizava nos anos anteriores. Os nazistas produziam cada vez mais programas....". ${ }^{15}$ Nos últimos anos da República de Weimar houve um crescente combate à politização da cultura operária: a propaganda nazista passa a ganhar volume e terreno.

"Em 1932, a organização nazista do rádio foi subordinada a Goebbels. Este fato é significativo se considerarmos que um censo da época mostrava um dado de suma importância para os interesses do Reich. O número de receptores de rádio chegava a 5 milhões, o que pressupunha uma audiência potencial de 15 milhões de pessoas. A elas chegavam as mensagens que o governo difundia, com seu próprio estilo e estratégia."16 Hitler já havia escrito sobre o rádio, nos anos 20, em seu livro Minha Luta: "É uma arma terrível em mãos que saibam usála." ${ }^{17}$ Hale considera que os nazistas foram os primeiros que perceberam e desenvolveram o uso do rádio como meio de propaganda ideológica.

Mas o rádio, apesar de seus poderes peculiares, foi apenas um dos instrumentos no arsenal da propaganda nazista. "Foi parte de uma rede firmemente interligada, organizada e coordenada pelo Propagandaministerium. As técnicas e os meios utilizados pelo Partido Nazista com tanto êxito para chegar ao poder na Alemanha foram, depois de 1933, ajustados a todo o aparato coercitivo do Estado." 18 E Hale continua: "Dentro da Alemanha, todos os meios falavam uma só voz, eram colocados obstáculos no caminho das fontes exteriores de informação e, conhecendo profundamente o público, os propagandistas puderam adaptar seus instrumentos psicológicos para ajustar-se aos medos, às esperanças e aos preconceitos do público. A própria natureza da propaganda alemã exigia que fosse monopolista e unitária."19 Além da utilização intensiva de todos os meios de comunicação disponíveis, a ação militar bem sucedida era fundamental para que o público fosse cativado. Mesmo a célebre Blitzkrieg radiofônica era uma técnica eficiente somente quando utilizada para reforçar a ação militar paralela.

$\mathrm{Na}$ época em que Brecht escreveu os textos da Teoria do Rádio, a Alemanha vivia um período peculiar. Durante a República de Weimar "pairava no ar a presença de uma violenta transformação social. Vivia-se numa fase da história desta formação social específica, em que a classe dominante havia perdido as rédeas do controle social, mas ainda não havia surgido uma classe (o proletariado) para assumi-lo". ${ }^{20}$

\section{Arma de transformação social}

As críticas de Brecht ao meio radiofônico merecem ser analisadas à luz dos novos rumos que a tecnologia tem propiciado. "Em uma época de grande privação econômica e moral, o rádio foi saudado como um milagre liberador e considerado como um fator de cultura cujas repercussões na vida cultural, política e econômica não puderam ser suficientemente avaliadas." 21

Uma das críticas mais veementes que Brecht fazia ao rádio, já em 1927, continua válida: o rádio ainda é, basicamente, um meio de distribuição de mensagens, não um meio de comunicação. Brecht, em suas propostas, fortalecia sempre a idéia de que o funcionamento do rádio, para ser positivo, deveria ser mudado: "É preciso transformar o rádio, convertê-lo de aparelho de distribuição em aparelho de comunicação." $22 \mathrm{E}$ ressaltava que sua função não se esgota em apenas transmitir informações sobre os acontecimentos. Ë necessário que o rádio promova, efetivamente, $\mathrm{o}$ intercâmbio entre a fonte e o destinatário para que o processo de dupla mão-de-direção se efetive. Mesmo o diálogo mental, indispensável para que o ouvinte reaja à mensagem, muitas 
vezes não acontece: o emissor se preocupa em tomar todo o espaço não permitindo que o ouvinte possa participar do processo comunicativo.

Algumas vezes, Brecht é categórico: "Em minha opinião, vocês deveriam fazer do rádio um meio verdadeiramente democrático. Com isto obteriam de imediato toda uma série de resultados se, por exemplo, dispondo (como dispõem) de maravilhosos aparelhos de difusão, deixassem de simplesmente produzir sem cessar e passassem a tornar produtivos os acontecimentos atuais mediante sua simples exposição e, em casos especiais, utilizando-se de uma direção hábil e que economize tempo.” E vai ainda mais longe em suas recomendações: "Opino que vocês deveriam aproximar-se mais dos acontecimentos reais com os aparelhos e não limitar-se somente à reprodução ou informação.”23

Nas declarações de Brecht fica claramente exposta não apenas sua posição quanto às possibilidades do rádio interativo, como meio de comunicação com duas mãos-dedireção mas, acima de tudo, a potencialidade do rádio como meio jornalístico, sem deixar de considerar também os outros gêneros de programas como musicais, radioteatro etc.

"Além disso, vocês podem preparar para o microfone, em lugar de resenhas mortas, entrevistas reais em que os entrevistados tenham menos oportunidade de inventar mentiras elaboradas, como podem fazer quando se trata de uma entrevista para os jornais." 24 Aqui, não podemos deixar de pensar que, com as novas tecnologias, o jornalismo digital, on line, pode, além de apresentar o texto de matérias feitas a partir de entrevistas com as fontes, disponibilizar as próprias entrevistas na íntegra, propiciando ao leitor/ouvinte não apenas conhecer as idéias e informações que o entrevistado tem para apresentar, editadas para publicação por critérios próprios a cada veículo. É a oportunidade para que o leitor/ouvinte conheça muito mais, não apenas $o q u \hat{\text {, }}$ mas o como foi dito.

Mais do que reconhecer no rádio sua pontencialidade jornalística, Brecht clama pela presença de um jornalismo de natureza substantiva, cumprindo na íntegra uma das características básicas da mensagem radiofônica: o imediatismo. ${ }^{25}$ Quando Brecht afirma que o rádio não deve limitar-se à reprodução ou simples informação do acontecimento, ele está colocando-se frontalmente em oposição ao jornalismo de natureza adjetiva. Os conceitos de jornalismo de natureza substantiva ou adjetiva envolvem a presença ou não do palco da ação, ou seja, se a emissão é direta - ou não - do local do acontecimento.

\section{$\mathrm{O}$ jornalismo de natureza}

substantiva pressupõe a transmissão ao vivo, a emissão direta, feita simultaneamente ao acontecimento. $\mathrm{O}$ emissor - no caso, o jornalista responsável pela transmissão -, elabora a mensagem conforme o desenrolar dos acontecimentos e o receptor - o ouvinte recebe a informação imediatamente, sem defasagem de tempo maior do que a necessária para essa elaboração verbal da mensagem que está, inclusive, sujeita à emocionalidade do palco da ação.

Ao contrário, em seu grau máximo de natureza adjetiva o jornalismo pode chegar a níveis extremos, muito bem representados na frase do jornalista Walter Sampaio: "Notícias mortas, irias, geladas, que são autopsiadas pela gillette-press". A emissão é sempre indireta, ou seja, existe uma defasagem de tempo entre o acontecimento e sua transmissão. $\mathrm{O}$ fato pode ser transformado em texto ou, se existe gravação, esta é editada. Acima de tudo, no jornalismo de natureza adjetiva existe um controle muito maior - poderíamos quase dizer total - do emissor sobre o conteúdo da mensagem. É significativo que nos regimes totalitários - ou em momentos de forte
(23) "Sugestões aos diretores artísticos do rádio "foi publicado, originalmente, em 25 de dezembro de 1927 no Berliner BörsenCourier sobottulo "Podemos programas radiofônicossermais autênticos e mais atuais?"; na matéria, ojomal colhia as opiniões do diretorartístico da

Radiodifusão Berlinense, Carl Hagemanneassugestões de Brecht Ibid., p. 50-51 (gnifos do autor).

(24) Ibid., p. 51.

(25) Os conceitos do jomalismo de natureza substantiva ede natureza adjetiva são desenvolvidos por WalterSAMPAIO no /ivo

Jornalismo Audiovisual - teoria e prática do jornalismo no rádio, TV e cinema. Petrópolis, Vozes, 1971, p. 72. Oautor apresenta os conceitos parao jomalismo televisionado, mas eles podem failmente ser transpostos para ojomalismo radiofônico. 
censura ass transmissões ao vivo, quando existem, limitam-se a reproduzir os acontecimentos oficiais e a ouvir as vozes oficiais. Todo o restante é abordado sob o ponto de vista do jornalismo de natureza adjetiva.

No caso brasileiro, esta relação fica bastante evidente. A partir de meados dos anos 60 e durante quase toda a década de 70, o jornalismo radiofônico (assim como o televisivo) foi reduzido a sua essência puramente adjetiva: textos redigidos e entrevistas editadas, sempre extremamente curtas (dificilmente eram mantidas as perguntas feitas pelos repórteres), limitando-se à informação sobre algum fato, nunca permitindo a exposição de juízos de valor, a sustentação de opiniões, a discussão de idéias (o que requer um tempo mais longo uma vez que é necessário apresentar os argumentos para que a opinião expressa conquiste adeptos). Os programas de entrevistas e debates (que Brecht também já sugeria) praticamente desapareceram com exceção dos esportivos; os jornalistas não precisaram mais falar de improviso. Como conseqüência, repórteres, entrevistadores, moderadores de debates, comentaristas etc. quase deixaram de existir no radiojornalismo e, até hoje, continuam persistindo os efeitos negativos: toda uma geração de jornalistas não pôde exercer suas funções de acordo com os requisitos exigidos pelas próprias características do meio radiofônico. Com o processo de abertura política foi necessário dar voz não apenas aos ouvintes, os receptores das mensagens: foi necessário, antes de mais nada, que os profissionais da comunicação, os emissores, recuperassem seu direito a ter voz sem censura oficial e, situação paradoxalmente mais complexa, aprendessem a ter voz sem autocensura. E para que todos tenham domínio sobre o direito de ter voz é necessário, antes, resgatar a própria cidadania, com seus direitos e deveres.
Brecht também já percebia - e se preocupava - com o controle do Estado sobre a radiodifusão. E reconhecia que, para explorar plenamente as potencialidades do rádio como meio de comunicação, muitas barreiras surgiriam: “...Haverá, seguramente, uma série de leis que tentarão impedi-lo. Será necessário dirigir-se à opinião pública para suprimir essas leis." 26 Esta previsão concretizou-se e persiste em todos os tipos de mensagens, principalmente nas jornalísticas. Por outro lado, Brecht não levou em consideração que com a grande proliferação de emissoras, alguma forma de regulamentação precisaria existir para que as transmissões não sofressem interferências de tal ordem que tomassem impossível receber as mensagens. Mas a regulamentação técnica não poderia ter a força de controlar os conteúdos. Esta discussão é muito atual com relação à Internet, espaço que tem muitos defensores da liberdade total; contudo, crescem cada vez mais os clamores de vários setores da sociedade pela regulamentação, pelo controle efetivo dos conteúdos que essa própria tecnologia permite.

$\mathrm{O}$ caráter comercial que o rádio tomaria, transformando-se em um grande negócio, também foi antevisto por Brecht. No final de "Sugestões aos diretores artísticos do rádio", ressalta: "E, para concluir, é requisito indispensável que vocês prestem contas, publicamente, das fabulosas somas que o rádio arrecada e expliquem a aplicação desse dinheiro público até o último centavo."27

Em qualquer dos sistemas de exploração da radiodifusão, o dinheiro empregado em sua manutenção é sempre público. Se a emissora é explorada comercialmente, na chamada livre iniciativa, as verbas para a manutenção da radiodifusão são oriundas da veiculação de anúncios publicitários: o custo recai sobre os produtos ou serviços anunciados e, 
conseqüentemente, sobre o consumidor destes produtos ou serviços. Se a emissora é estatal, seja no sistema pluralista (no qual convivem emissoras comerciais e estatais), seja no sistema monopolista (o Estado detém o monopólio, explorando a radiodifusão diretamente), as verbas são originadas nos tributos pagos pelo cidadão ao Estado (em alguns países vigora o pagamento de licenças para que se possa ter um receptor). Vale ressaltar que, no caso da exploração comercial, muitas vezes o cidadão paga duplamente para a manutenção dos meios de comunicação, uma vez que o Estado é um dos maiores anunciantes. Portanto, se é o próprio ouvinte quem subsidia os meios de comunicação, é um direito básico deste ouvinte cobrar das empresas de radiodifusão um retomo condizente.

Para Brecht, o rádio deveria sempre empenhar-se em assumir sua importância social, que vai muito além de simples meio de lazer, de entretenimento, sem maiores conseqüências. $\mathrm{O}$ rádio precisa estar estreitamente ligado à realidade, mas não de forma meramente decorativa. Ao contrário, influenciando e modificando essa realidade. "Todas as nossas instituições ideológicas acreditam que sua missão principal seja manter intranscendente o papel das ideologias, de acordo com um conceito de cultura segundo o qual sua configuração já está terminada e a cultura não tem necessidade de nenhum esforço criador continuado." 28

Quando surge uma inovação técnica com tantas utilidades, para distintas funções sociais como o rádio, ocorre, segundo Brecht, "um esforço angustiante para manter-se intranscendentemente em passatempos que, quanto mais inofensivos forem, melhor". Como resultado, não haverá um vínculo criativo entre emissor e receptor, uma mútua realimentação, um processo efetivo de comunicação. E de interatividade. "Então, não é possível conter a pergunta se não existe nenhuma possibilidade de evitar o poder da desconexão mediante a organização dos desconectados. (...) O público não deve apenas ser instruído, mas instruir também."29

\section{Da teoria para a prática}

Se, por um lado, concordamos com a validade e a lucidez de muitas das propostas e críticas que Brecht fez ao rádio, inclusive quanto à pertinência da terminologia empregada, por outro, precisamos levar em consideração o momento, o estágio, a evolução da sociedade e da tecnologia nestes anos que separam as reflexões que compõem a Teoria do Rádio de nossos dias. Alguns momentos foram históricos e essenciais neste percurso. E nem sempre devidos à evolução da tecnologia: muitas vezes, a compreensão da linguagem do meio radiofônico, o primeiro dos media eletrônicos, criou marcos divisores reconhecidos e respeitados até hoje.

No especial do Radioteatro

Mercury da véspera do Dia das Bruxas de 1938 - denominado Mercury's

Halloween Show -, através dos sons, foi representada uma invasão de marcianos do ponto de vista de uma cobertura jornalística. Todas as características do radiojornalismo usadas na época - às quais os ouvintes estavam habituados e nas quais acreditavam - se faziam presentes: reportagens externas, entrevistas com testemunhas que estariam vivenciando o acontecimento, opiniões de especialistas e autoridades, efeitos sonoros, sons ambientes, gritos, a emotividade dos envolvidos, inclusive dos pretensos repórteres e comentaristas, davam a impressão de um fato real, que estava indo ao ar em edição extraordinária, interrompendo outro programa, o radioteatro previsto. ${ }^{30} \mathrm{Na}$

(28) Ibid., p. 57. (29) Ibid., p. 58. realidade tratava-se do $17^{\circ}$ programa da série semanal de adaptações radiofônicas realizadas pelo então jovem ator e diretor Orson Welles e o Radioteatro Mercury que explorava as técnicas (30) SIMON, William G. "The Man
and the Myth". In: New York University Magazine, Inverno 1987, p. 22. 
(31) Sobreo assunto, vide: MEITSCH, Eduardo(org.). Rádio e Pânico: a Guerra dos Mundos, 60 anos depois. Forianópolis, Editora Insular, 1998.

(32) Garcia Camargo, Jimmy. La radio por dentro e por fuera. Quito, Ciespal, 1980, p. 19.

(33) Bossetti, OscarE.

Radiofonías - palavras y sonidos de largo alcance. Buenos Aires, Colihue, 1994, p. 70. (34) Ibid., p. 50. jornalísticas com a ambientação sonora requerida. Mais que isso: havia compreendido, na prática, que mesmo o gênero jornalístico não dispensa o respeito absoluto à linguagem radiofônica. ${ }^{31}$ "O impacto foi tal que mesmo Orson Welles se surpreendeu quando milhares de pessoas saíram às ruas, angustiadas e em pânico; algumas, desejosas de testemunhar um fato que, acreditando verdadeiro, lhes parecia significativo e histórico." 32

A CBS calculou na época que o programa foi ouvido por cerca de seis milhões de pessoas, das quais metade passou a sintonizá-lo quando já havia começado, perdendo a introdução que informava tratar-se do radioteatro semanal. Pelo menos 1,2 milhão tomaram a dramatização como fato verídico, acreditando que estavam mesmo acompanhando uma reportagem extraordinária. E, desses, meio milhão tiveram certeza de que o perigo era iminente, entrando em pânico e agindo de modo a confirmar os fatos que estavam sendo narrados: sobrecarga de linhas telefônicas interrompendo realmente as comunicações, aglomerações nas ruas, congestionamentos etc.

"Obviamente, desde aquela noite do final de outubro de 1938 até nossos dias, novas problemáticas foram se incorporando ao complexo campo das Ciências da Comunicação em geral e da radiodifusão em particular. No entanto, de tempos em tempos, os marcianos imaginados por Welles se materializam em patéticas silhuetas de carne, ossos e metal. E, então, o pânico ou a indiferença atravessam a história através de um atento, impassível receptor de rádio." 33

O episódio mostrou a força do rádio e seu poder na formação da opinião pública, além das possibilidades de manipulação que o meio propiciava. Mas o efeito imediato mais importante foi o surgimento de uma série de pesquisas teóricas e práticas que, até então, eram esporádicas e pouco sistematizadas. Tendo o rádio como centro de investigação, os pesquisadores se viram frente a uma problemática mais complexa: a das audiências. E começaram, com diversas denominações, os estudos sobre os processos de mediação e as práticas de recepção de forma sistematizada, não apenas do rádio mas da comunicação social em geral.

Merecem ser citadas as pesquisas feitas, na época, por Hadley Cantril, psicólogo da Universidade de Princeton, que em 1940 publicou um dos primeiros estudos decisivos sobre o fenômeno do rádio como meio de comunicação. Suas conclusões colocamvam em evidência a importância do papel dos ouvintes e os espaços - público e privado - que os circundavam.

A Guerra dos Mundos cria um antes e um depois. Para o rádio, “ 1938 é um ano que encerra o ciclo da protohistória do meio idealizado por Marconi e abre outro sinuoso e imprevisível que se prolonga até estes insípidos e pasteurizados dias do final do século". 34

Em termos locais, experiências foram sendo realizadas em várias partes mostrando as potencialidades do rádio e seu papel mobilizador. No mesmo ano de 1938, por exemplo, o Campeonato Mundial de Futebol, realizado em junho na França, foi palco, fora das campos, de importante marco do rádio brasileiro: a primeira transmissão esportiva, em cadeia nacional, diretamente da Europa. Os cinco prélios dos quais o scratch brasileiro participou, mais o match final que decidiu o certamen, foram irradiados por Gagliano Neto para a Cadeia de Emissoras Buyngton. Formada pelas rádios Clube do Brasil e Cruzeiro do Sul do Rio de Janeiro, Cosmos e Cruzeiro do Sul de São Paulo, além da Rádio Clube de Santos, em colaboração com os jornais O Globo e Jornal dos Sports, tudo sob o patrocínio exclusivo do Cassino da Urca, teve 
sucesso imediato. Conforme o team patrício, constituído por moços fortes, fazia cair os adversários, outras emissoras, de norte a sul, de leste a oeste do país foram se integrando à performance espetacular daquele meio de comunicação que, como o futebol, empolgava as multidões. Foi uma façanha digna dos intrépidos homens do rádio daqueles tempos que em muito contribuiu para que se conhecesse melhor a prática radiofônica. ${ }^{35}$

A práxis do rádio em seu dia a dia foi decisiva para consolidar a teoria incipiente sobre o novo meio de comunicação. Para trabalhar com a dupla mão-de-direção é necessário levar em consideração as motivações dos ouvintes para que participem ou não do processo comunicativo, do diálogo mental entre emissor e receptor. $\mathrm{O}$ rádio precisa cumprir seu papel social informando, educando, formando etc., mas sem esquecer que este processo deve ser prazeiroso, agradável, espontâneo, permitindo que o ouvinte participe, relaxe, tenha seu lazer e entretenimento. $\mathrm{E}$ que os hábitos culturais de cada grupo sejam respeitados.

Outro ponto a ser discutido é a qualidade das produções a partir do momento em que todos - ou, pelo menos, muitos grupos - produzissem programas. Chegaríamos à reprodução do discurso face-a-face, talvez com alguns efeitos - ou enfeites - sonoplásticos. A qualidade destas produções certamente deixaria muito a desejar. Em determinadas ocasiões, quando os fatos são extremamente importantes para a sociedade, a qualidade pode ser deixada em plano secundário. Mas, na rotina, ela deve estar em pé de igualdade com o próprio conteúdo do programa. Há que se considerar a diferença essencial entre utilizar a linguagem radiofônica como meio de comunicação ou, apenas, as ondas radiofônicas como simples suporte para a ampliação do discurso interpessoal.

Sem dúvidas, o rádio pode ser encarado como um meio mobilizador a partir do envolvimento físico com o processo. Assim como durante a República de Weimar os trabalhadores sentiam-se participantes ao montarem seus receptores, também a produção de programas pode levar os indivíduos a despertarem para outros âmbitos de interesse, para a participação política ou a mobilização comunitária. As duas mãos-de-direção pregadas por Brecht ou a interatividade dos dias atuais continuam se debatendo entre rosas e espinhos que passaram a merecer la estudos teóricos e experiências práticas sob a chancela de diferentes escolas de pensamento.

\section{Da produção para a recepção: pensando o sujeito}

Estudar o processo de comunicação do ponto de vista da pesquisa do receptor não é uma abordagem nova. Mas o retomo do interesse por seu conhecimento, como afirma Nilda Jacks, "corresponde a uma saída teórica e política para os problemas de comunicação, especialmente do Terceiro Mundo, em que a América Latina desponta com propostas que avançam na compreensão da relação entre cultura e comunicação". 36 Esta abordagem se opõe aos estudos feitos por correntes de pensamento que "reavaliam o uso de análises globalizantes", mas que não trabalham com a importância do reconhecimento do sujeito nesse processo. Para Jacks, "o novo, na retomada dos estudos de recepção", é o tratamento dado ao processo de recepção, "é considerar o receptor o sujeito do processo e da própria pesquisa".

A partir desse enfoque, as noções de cultura e de comunicação foram aproximadas, "resultando nas mediações como objeto de estudo; a escolha do cotidiano como espaçotempo de análise; o reconhecimento dos
(35) Sobre o assunto, vide: ORTRIWANO, Gisela Swetlana.

"França 1938, III Copa do Mundo: o rádio brasileiro estava lá". In: GT História e Comunicação/XXII Intercom, 1999(disquete). (36) JACKS, Nilda. "Pesquisa de recepção e ailtura regional"'p. 151. In: SOUSA. Mauro Witon (org.). Sujeito, o lado oculto do receptor. São Paulo, Brasiliense, 1995, pp. 151-165. 
(37) Ibid., p. 152-153.

(38) HA YE, Ricardo M. Hacia una nueva radio. Buenos Aires,

Paidós, 1995, pp. 28-29.

(39) Ibid., pp. 27-29. Haye baseia

sua proposta no informe acadêmico

do "ISeminario-Taller

Latinoamericano de Metodologia de

la Enseñãnza de la Radio",

organizado pela 1 \#AFACS-

Federacón Latinoamericana de

Facultades de Comunicación

Social - realizado em Bogotá,

Colômbia, de 19a29de

novembro de 1991.

(40) LFWIN, Kurt "Frontiers in

Group Dynamics II. Channels of

Group Life: Social Planning and

Adtion Research". In: Human

Relations, vol. 1, n², p. 145

(atado por WOLF, Mauro. Teorias

da comunicação, 4 ed., Lisboa,

Presença, 1995, pp. 161-162).

(41) BEITRÃO, LUі.

Folkcomunicação - a

comunicação dos

marginalizados. São Pauto,

Cortez, 1980, p. 24. receptores populares como sujeitos capazes de produção de sentido." O "lugar privilegiado para abordar as mediações tende a ser o cotidiano" e o fato de "deslocar o eixo das pesquisas para as mediações não significa desconsiderar a importância dos meios, mas evidenciar que o que se passa na recepção é algo que diz respeito ao seu modo de vida, cuja lógica deriva de um universo cultural próprio, incrustado em uma memória e em um imaginário que são decorrentes de suas condições concretas de existência". ${ }^{37}$

Historicamente, existiram várias formas de pensar o rádio. Uma das correntes atuais que parecem mais promissoras é exatamente a que faz a abordagem como uma experiência cultural. Os "meios não são instrumentos, mas também não são meros produtores culturais. Os meios são também produtores e modeladores de cultura". ${ }^{38}$ Deste ponto de vista, Haye apresenta duas grandes perspectivas a partir das quais se deve pensar o rádio. O primeiro "modo teórico e conceitual" de abordá-lo foi entendê-lo como meio de difusão. "Ou seja, meio como canal de transmissão de mensagens que buscam objetivos definidos", modelo que tem seus primórdios já nos anos 40 . Este modelo, que aparece em correntes funcionalistas, pode ser analisado tanto sob o ponto de vista de que "o rádio é um meio capaz de veicular conteúdos para mudar atitudes" ou outra, em que o rádio é visto como "um meio de imposição: o rádio é manipulador, está ligado ao poder, é um meio de dominação". A segunda vertente apresenta-o como uma prática significante, em que o rádio "não é pensado como um canal através do qual se transmitem conteúdos, mas como um espaço no qual diferentes atores desempenham diferentes papéis, produzindo o sentido em conjunto. Em conseqüência, nesta concepção já não se pensa em emissores ativos e receptores passivos, mas que ambos adquirem um papel produtivo". Assim, podemos concluir que "o público do rádio não é objeto de um processo mas parte integrante da prática comunicativa, estando presente nas estratégias de produção e emissão". Haye afirma que "dentro deste modelo existe outra linha que não é contraditória mas complementar: pensar o rádio como uma experiência cultural. $\mathrm{O}$ rádio é uma das formas através das quais os indivíduos produzem cultura. ${ }^{39}$ A partir desta perspectiva podem ser feitos estudos qualitativos permitindo, também, abordar a dimensão estética dos meios, outorgando importância ao papel dos receptores no processo.

$\mathrm{O}$ conceito de gatekeeper foi elaborado por Kurt Lewin em estudo de 1947 sobre as dinâmicas que agem no interior dos grupos. Identificando os canais por onde flui a seqüência de comportamentos relativos a um determinado tema, Lewin nota que existem neles zonas que podem funcionar como cancela, como porteiro: "O conjunto das forças, antes e depois da zona filtro, é decididamente diferente, de tal forma que a passagem, ou o bloqueio, da unidade através de todo o canal, depende, em grande medida, do que acontece na zona filtro. Isso sucede não só com os canais de alimentação mas também com a seqüência de uma informação, dada através dos canais comunicativos, num grande grupo." 40

Estudando a vinculação estreita entre folclore e comunicação popular no nordeste brasileiro, Luiz Beltrão cunhou a nomenclatura folkcomunicação para o processo definindo-o como "o conjunto de procedimentos de intercâmbio de informações, idéias, opiniões e atitudes dos públicos marginalizados urbanos e rurais, através de agentes e meios direta ou indiretamente ligados ao folclore". ${ }^{41}$ Segundo Beltrão, a folkcomunicação preenche hiatos de comunicação das camadas populares, exprimindo-se em linguagem 
e códigos que refletem "o viver, o querer administrativos ou música erudita, não e o sonhar das massas populares excluídas por diversas razões e circunstâncias do processo civilizatório".

Se pensarmos a folkcomunicação como um sistema do processo mediático, "as manifestações são sobretudo resultado de uma atividade artesanal do agente-comunicador, enquanto seu processo de difusão se desenvolve horizontalmente, tendo-se em conta que os usuários característicos recebem as mensagens através de um intermediário próprio em um dos múltiplos estágios de sua difusão. A recepção sem este intermediário só ocorre quando o destinatário domina seu código e sua técnica, tendo capacidade e possibilidade de usá-lo, por sua vez, em resposta ou na emissão de mensagens originais". Beltrão completa: "A folkcomunicação é, por natureza e estrutura, um processo artesanal e horizontal, semelhante em essência aos tipos de comunicação interpessoal já que suas mensagens são elaboradas, codificadas e transmitidas em linguagens e canais familiares à audiência, por sua vez conhecida psicológica e vivencialmente pelo comunicador, ainda que dispersa. "42

$\mathrm{O}$ rádio é "o mais usual dos meios de massa entre as camadas populares, especialmente depois da invenção do transistor", segundo Beltrão. E os ouvintes ou audiência folk, como a denomina, conseguem, por exemplo, entender e reagir bem a mensagens futebolísticas pois conhecem as regras do jogo, seus termos e expressões; os programas religiosos, principalmente os cultos de cunho afro-brasileiro; os programas de música sertaneja, entre outros. São mensagens cujas sintaxes, na opinião do autor, são mais singelas e conduzidas com empolgação, "tipo de eloqüência muito apreciado pelas massas". Quanto a outras mensagens, como assuntos econômicos, políticos, fazem parte do cotidiano do ouvinte, "caem na vala comum da incompreensão, ainda mesmo quando recebidas por grupos de ouvintes interessados...", necessitando o emprego de intermediários para que sejam compreendidas. ${ }^{43}$

Beltrão afirma que "a identificação do líder de opinião como agentecomunicador do sistema de folkcomunicação foi o ponto de partida do trabalho desenvolvido por quantos se dedicaram à busca e análise dos agentes e usuários do processo, das modalidades e dos feitos da grande corrente paralela de mensagens que permitirá $o$ conhecimento das expressões do pensamento popular, do seu intercâmbio de idéias e, afinal, das tentativas de uma convivência, quando não da integração, entre grupos tão fundamentalmente distanciados". ${ }^{44}$

A influência dos meios de comunicação de massa se exerce não diretamente, mas através de intermediários, tais como o líder de opinião, o agente de comunicação, o mediador que, acima de tudo, ouve e se faz ouvir no processo de emissores oficiais/ emissores populares, dando espaço para o feedback, para a interação com o receptor.

Néstor Garcia Canclini afirma que ao falar de cultura, precisamos pensar que "são processos sociais e, parte da dificuldade de falar de cultura está no fato de que circula, é produzida e consumida na sociedade. Não é algo que continue sempre da mesma maneira. Daí a importância que adquiriu a teoria da recepção ou os estudos sobre recepção e apropriação de bens e mensagens nas sociedades contempo-

(42) Ibid., pp. 26-28 (grífos do

râneas pois mostram como um mesmo

objeto pode transformar-se em seu uso social". ${ }^{45}$

\section{Crise conjuntural II: as rádios comunitárias}

No cenário globalizado a tecnologia é um dos campos mais

\author{
autor). \\ (43) Ibid., p. 28. \\ (44) Ibid., p. 31. \\ (45) CANCINI, Néstor Garcá. \\ Cultura y comunicación: entre \\ lo global y lo local. Buenos Aires, \\ Universidad Nadonal de la Plata, \\ 1997, p. 36 (grifos do autor).
}


(46) MARTÍN-BARBERO, Jesús. "América Latina eos anos recentes: o estudo da recepsão em comunicacão socall', p. 39. In: SOUSA, Mauro Wilton (org.), Op. at, pp. 39-68. (47) MAFTESOU, Michel. No fundo das aparências. São Paulo, Vozes, 1996.

(48) PADILAFRNÁNDEZ, Adrián José. Democratização do ar como exercício de cidadania. São Paulo, ECANUSP, 1998 (mestrado), p. 47. (49) Ibid., p. 48. significativos. Um único e grande mercado em que fenômenos, antes localizados, passam a ter importância mundial: o desemprego que ocorre em um país tem origem em ajustes promovidos em outro lado do planeta. A revolução que as novas tecnologias causaram nas comunicações e nas relações humanas individuais e grupais, mudou as noções de tempo e espaço e, certamente, o universo informativo permitiu que o coletivo social seja testemunha ao vivo, via satélite, de tudo quanto acontece no mundo. A globalização se dá em todos os níveis, tanto econômicos como políticos, sociais e, sobretudo, culturais.

A recepção não é apenas mais uma das etapas do processo de comunicação mas, como diz Jesús Martín-Barbero, “é um lugar novo, de onde devemos repensar os estudos e a pesquisa de comunicação". $46 \mathrm{Se}$, por um lado, fala-se de uma cidadania global, resultado dos efeitos proporcionados pela tecnologia, envolvendo satélites, TV a cabo, Internet etc., por outro, está surgindo uma revalorização do local, do comunitário, como espaço próprio para o exercício da cidadania, que para Michel Maffesoli é a tribalização, um dos signos da contemporaneidade ou o espírito do tempo pós-moderno.. ${ }^{47}$

"Para tentar situar o conceito de cidadania neste tempo globalizado, devemos levar em conta alguns fatos significativos. Por uma parte, vivemos em um mundo mediático, quer dizer, que a maior parte de nossos conhecimentos e experiências quanto a desejos, aspirações, valorizações e emoções estão 'mediatizados' pela mídia. Por outra, o impacto tecnológico reflete-se com maior força no campo das comunicações e em tomo aos meios constituem-se grandes empresas transnacionalizadas. Nesse contexto, a experiência comunicativa vira um mercado tão global como qualquer atividade econômica. O desafio é definir, ou redefinir, a relação meios de comunicação e cidadania em um momento de mudanças significativas, em um mundo que deixou de ser mais geopolítico para ser mais geoeconômico e, sobretudo, mais geocultural."48 A "possibilidade de abrir espaços de comunicação alternativa através das rádios comunitárias, dentro de um quadro onde a monopolização dos meios é o fato predominante, vem gerando fortes discussões que atingem os mais variados campos, mais especialmente o político e o econômico". 49

De maneira geral, o rádio ainda é encarado como meio de segunda categoria e um dos aspectos cruciais nesta questão continua sendo o sistema de exploração da radiodifusão, há muito atrelado a uma prática em que o critério básico para a concessão é o do jogo político, da amizade, da troca de favores. O interesse social e a competência tomam-se secundários nesse processo. Para que haja mudanças efetivas, o rádio precisa de investimentos, não apenas na área financeira, mas na própria reformulação do sistema de concessões para que os canais passem a ser usufruídos por aqueles realmente interessados em um meio de comunicação. As emissoras estatais, cumprindo o papel da utilização social, devem conviver com emissoras comerciais, coexistindo com os canais de uso comunitário e o rádio local, produzindo e difundindo mensagens da e para a comunidade. Estas emissoras deverão estar sob o efetivo controle de grupos sociais e não, como ao que tudo indica, tomarem-se novamente portavozes de interesses políticos que as controlem via intermediários.

As empresas de radiodifusão vivem uma difícil fase de transição. Por um lado, a redemocratização da sociedade brasileira trouxe à tona necessidades de comunicação até então mantidas caladas à força de leis e decretos; a tecnologia, por sua vez, ampliou as possibilidades de acesso à 
informação, acirrando ainda mais a concorrência pela audiência. Por outro, os avanços desta tecnologia estão colocando em xeque a competência de cada uma destas empresas, ameaçando quebrar a reserva de mercado em que estabeleceram seu modus operandi. A necessidade de acompanhar as inovações tecnológicas como a transmissão digital (DAB - Digital Audio na sociedade da informação o global Broadcasting) e, acima de tudo, a disputa que poderá surgir com a entrada de novos concorrentes dos ramos de telecomunicações ou informática (fortemente capitalizados), aumentam o temor: a extinção de empresas que sempre tiveram uma estrutura empresarial extremamente frágil. ${ }^{50} \mathrm{~A}$ implantação do rádio digital parece ser a forma natural de evolução do rádio analógico. No que se refere à produção e à administração, o processo já está em pleno desenvolvimento, reduzindo custos de mão-de-obra e melhorando a qualidade dos produtos oferecidos ao ouvinte. O problema maior dos radiodifusores diz respeito à transmissão e, no geral, reforçar as medidas que garantam a diminuição dos custos, alcançando a máxima rentabilidade para o setor. Tarefa árdua se pensarmos nos sérios entraves que se originam na ausência de projetos de filosofias e estratégias empresariais bem definidas.

Os conceitos de global e de local são importantes para o rádio em tempos de globalização, em que há uma crescente desterritorialização de bens e serviços, gerando crises de identificação não apenas individuais, mas também entre os espaços público e privado. $\mathrm{O}$ ouvinte precisa sentir que a emissora em que está ligado tem essa abrangência multifacetada: informa sobretudo o que estiver acontecendo no mundo, sem esquecer dos detalhes daquilo que está ocorrendo ao redor, seja do ponto de vista geográfico, estritamente físico, ou psicológico, em que a proximidade está relacionada às afinidades e ligações emocionais. E o rádio assume, não apenas o papel de meio de informação e entretenimento, mas também o de companhia e solidariedade.

"Mesmo a (...) realidade sendo mais complexa e a articulação entre tecnologia, economia, sociedade e espaço seja um processo aberto, variável e interativo, parece claro que condiciona o local e os fluxos eletrônicos estruturam a economia a partir de relações entre unidades espacialmente distantes. Mais ainda: a comunicação, na base das expressões culturais da sociedade e do imaginário dos indivíduos, está crescentemente globalizada a partir do sistema emergente de multimedia controlado financeira e tecnologicamente por grandes grupos internacionais, ainda que seus produtos se diversifiquem para segmentos específicos do mercado." 51

Segundo Borja e Castells, mesmo que as culturas locais, de base territorial, não desapareçam, terão de procurar formas de se relacionarem com alguns potentes meios de comunicação globalizados que "configuram em boa medida um hipertexto da comunicação e da interação simbólica". Para eles, o local terá importância estratégica como centro de gestão do global no novo sistema tecno-econômico, sob três âmbitos principais: o da produtividade e da competitividade, o da integração sócio-cultural e o da representação e gestão políticas.

$\mathrm{O}$ rádio se desenvolveu como modelo concentrador, criticado por Brecht desde o inicio uma vez que surgiram muitas entidades oferecendo um produto que praticamente não tinha demanda (na Alemanha, o rádio já era estatal na época), com a programação tendo "uma cara quando deveria ter duas", sendo um simples aparelho distribuidor. Neste sentido, Brecht conclamava os diretores de emissoras a abrir canais de participação dos ouvintes na formação da programação,
(50) A respeito, vide: ORTRIWANO, Gisela Swettana. "O radiojomalismo visto por dentro". In: Os (des)caminhos do radiojornalismo., Op. at, $p p$. 132-162. (51) BORIA, Jordie CASTELS, Manuel. Local y global - la gestión de las ciudades en la era de la informadón. Madrid, Taurus, 1997, p. 12. 
uma antevisão do que hoje fascina os estudiosos das novas tecnologias e, especialmente, da Internet, sob o nome de interatividade. Ainda rara no rádio brasileiro, a interatividade é exceção, concentrada principalmente nas emissoras dedicadas ao jornalismo. Nas demais, o direito do ouvinte é, praticamente, o de escolher sua predileta entre umas tantas músicas destacadas no programa. E concorrer a algum prêmio.

Nos anos 90, o celular permitiu a participação do ouvinte-repórter ${ }^{52}$ que, em algumas emissoras, de maneira espontânea, transmite informações e, teoricamente, pode estar em qualquer lugar dando ampla cobertura aos acontecimentos que presencia. $\mathrm{O}$ conteúdo dessas intervenções ainda é muito discutível, limitando-se a informações ligadas à prestação de serviços. Mas aos poucos, alguns passos estão sendo dados em direção à emissão da opinião de cada um. Falta, ainda, assimilar o conceito de cidadania para que as emissoras (e até amplas faixas da sociedade) aceitem permitir que o ouvinte expresse suas opiniões assumindo os riscos dessa participação ao vivo, substantiva. As experiências feitas nos últimos anos têm mostrado que os recursos tecnológicos estão sendo utilizados para que a comunicação entre emissor-receptor se estabeleça de forma ainda mais controlada, seja por causa da competência e do poder econômico envolvidos para que o receptor (ou usuário?) tenha acesso à emissoras via Internet, fax etc., recursos que permitem o controle total por parte do emissor. $\mathrm{O}$ mesmo ocorre com o telefone, celular ou não, que sempre pode ter sua linha derrubada de acordo com as conveniências de quem tem o poder de determinar os conteúdos

"A segunda metade dos anos 90 parece estar marcada pela acomodação do rádio ao surgimento de uma concorrente, a Internet, que busca apropriar-se de seus procedimentos. No entanto, a Internet parece ter sido um meio mais generoso com o rádio do que a TV: ao apropriar-se de seu knowhow, a NET o faz explicitamente, usando não só de seu estilo, mas todos os seus procedimentos. As emissoras de rádio estão migrando para o suporte informático mantendo integralmente seu estilo e sua marca. Assim, hoje tanto é possível mandar um e-mail para o rádio quanto ouvir um programa no computador." 53

Os caminhos trilhados para o resgate da cidadania plena no Brasil são muito recentes, assim como são recentes os avanços da tecnologia. É necessário aprofundar o conhecimento do universo cultural dos receptores para a concepção, planejamento e avaliação das experiências e projetos de rádio. Quanto ao rádio local e as emissoras comunitárias (ou cornetas, livres, piratas) que utilizam recursos dos mais simples aos mais sofisticados como alto-falantes, satélites, Internet etc., a preocupação merece atenção especial. e $\mathrm{O}$ desconhecimento desse universo presente no cotidiano da população, compromete o desenvolvimento das experiências, o conhecimento da realidade entre produtores e receptores no processo de construção de uma comunicação que atinja as expectativas e necessidades de emissores e receptores.

As redes de emissoras que estão se popularizando no Brasil nesta última década - apesar de várias tentativas anteriores - dando cobertura a amplos espaços geográficos (relembrando o início dos tempos do rádio, principalmente nos EUA, com a cobertura costa-a-costa e as transmissões em Ondas Curtas), por meio da interligação de emissoras de pequeno alcance (conceito de glocal), trabalhando com a proximidade (o local) e com a globalização. Ë, talvez, o caminho da cobertura que atenda à proximidade (tanto física quanto psicológica) e a 
abrangência geográfica, ao mesmo tempo em que permite a implantação de estratégias empresariais que garantam a sobrevivência econômica das emissoras.

\section{Tecnologia: volta ao princípio?}

As empresas radiofônicas logo perceberam a necessidade de destinar mensagens diferentes para pessoas diferentes: é a segmentação de públicos e de mercados. A partir dos anos 60 essa prática tomou-se comum nos Estados Unidos: emissoras que transmitiam apenas um determinado tipo de música (rock, clássica, country etc.); dramatizações (teatro, novelas); esportes; jornalismo (as chamadas emissoras all news) etc. No Brasil, a segmentação como proposta de programação começou a ser experimentada apenas nos anos 80, geralmente nas FMs e, atualmente é considerada, principalmente pelos profissionais de propaganda e marketing, como o caminho para a sobrevivência do rádio.

Em seus primeiros anos, o poder do rádio foi temido devido, principalmente, ao desconhecimento de suas potencialidades e conseqüências. Hoje, a situação não é muito diferente: mais que o poder do rádio, o poder da comunicação continua temido, agora via informática. É a vez da Internet ocupar o lugar central no palco das discussões, como meio para diferentes manifestações radiofônicas: suporte para as transmissões normais; emissoras virtuais, que existem somente na Internet; rádio on demand, ou seja, ouvir programas que já foram para o ar ou a disponibilização de outros arquivos sonoros, como gravações históricas, por exemplo. É a convergência, a soma dos media. É o caminho do surgimento de novos analfabetos que vão precisar de intermediários para se comunicar, a exemplo daquele representado pela personagem Dora no festejado filme Central do Brasil.
Alguns estudiosos receiam que a implantação de programas de tecnologia de comunicações e de informação possam ser realizados às cegas por governos que não se incomodem com as conseqüências sociais, algumas potencialmente devastadoras. Sempre houve, através da história, a suposição de benefícios implícitos advindos de novas tecnologias. Mas muitas vezes os impactos negativos demoraram para ser reconhecidos e suas conseqüências sociais freqüentemente suplantam qualquer benefício. O mesmo pode ser dito com razão de muitas tecnologias novas, como a realidade virtual, a Internet e os softwares inteligentes. $\mathrm{O}$ rádio vive um momento de grande vitalidade criativa. A informática tem se mostrado um importante aliado. Por meio de programas específicos, pode ser ouvido em qualquer lugar via Internet, satisfazendo a característica da proximidade psicológica mesmo que a distância física entre o emissor e o ouvinte seja muito grande: o amigo está lá, para muitos diálogos mentais, em seu papel de background, pano de fundo de qualquer atividade que esteja sendo desempenhada, sem requerer atenção exclusiva. Mas o acesso às novas formas de comunicação e a participação interativa exigem, não apenas competência, tecnológica mas também poder aquisitivo.

Com a informática, o rádio ganha novas perspectivas quanto ao seu potencial interativo. Hoje, já não são poucas as emissoras que incentivam a participação do ouvinte por e-mail, assim como por fax. O correio tradicional perdeu seu lugar uma vez que não acompanha a agilidade do rádio. Tomando a liberdade de ampliar a conceituação apresentada por Walter Sampaio para a natureza do jornalismo, a interatividade solicitada pelas emissoras é adjetiva. ${ }^{54}$ Via de regra, não é permitida a participação de viva voz, no que poderíamos chamar interatividade substantiva. $\mathrm{O}$ uso do telefone,
(54) Videnota 25. Anoção de jomalismo de natureza substantiva e/ou adjetiva foi aqui utilizada para a questão da interatividade, de acordo com o maior ou menor controle da participação física do receptor. No caso, não estamos considerando a interatividade envolvida na ariação do diálogo mental entre emissor e receptor. 
(55) "Obom texto, aurto egrosso".

II Seminário Internacional de Radiojomalismo-Espaço garantido no futuro (Suplemento Especial). In: Revista Imprensa, São Paulo, Ano X, $n^{\circ} 118$, julho 1997, p. 12. (56) JEUUNEK, Dan. "Espedalista adverte para perigos de programas decomunicacões". O Estado deS. Paulo, 04.04.1998, p. D6. (57) LÓPEZ VGIL, Josélgnacio. Manual urgente para radialistas apasionados. Quito, Ciespal/Amarc, 1997, pp. 21-22. convencional ou celular, apesar de recurso importante, oferece pouco espaço para o ouvinte uma vez que implica menor controle sobre o discurso, mesmo que pretensos problemas técnicos possam facilmente derrubar uma ligação telefônica indesejada.

O conceito de glocal desenvolvido pelo rádio quanto ao seu alcance $\mathrm{e}$ abrangência é resultado das novas tecnologias: ele é global e local, ao mesmo tempo. Primeiro aparelho eletrônico a entrar no universo doméstico, para Eduardo Meditsch a forma inicial de audição era muito parecida com a navegação que se faz hoje na Internet: "O interesse não era pelas noticias, mas para captar sinais distantes." Foi o primeiro meio a fazer transmissões em tempo real e lançou a idéia da interatividade. "O rádio é uma manifestação precoce da era eletrônica e não foi entendido antes porque o conceito de eletrônico não existia." ${ }^{55}$

Talvez Orson Welles tenha intuído, duas décadas antes, idéias desenvolvidas pelo canadense Marshall McLuhan(1912-1981),teóricodos meios de comunicação de massa e inventor da expressão aldeia global. Segundo McLuhan, durante pouco tempo o rádio foi um meio de entretenimento. Sua essência é a de meio informativo, revela mais claramente após o surgimento da televisão. Notícias, hora certa, informações sobre o trânsito, sobre o tempo, enfatizam o poder do rádio. Mas o rádio é muito mais.

A informação jornalística no rádio ocupa espaços cada vez maiores e as emissoras all news e talk radio fazem parte do cotidiano. Pecam, contudo, por esquecer a linguagem do rádio: além da informação, a correta ambientação sonora é fundamental. Do ponto de vista da moderna tecnologia, em A Guerra dos Mundos "um mundo virtual foi descrito e apoiado por um mecanismo que, na experiência dos ouvintes, era usado apenas para acontecimentos reais. A incapacidade de distinguir imediata e claramente o real do virtual foi a verdadeira causa do pânico". 56

"Atualmente, o rádio goza de excelente saúde. A emissão através das novas freqüências digitais (DAB), a difusão já não apenas das ondas hertzianas, mas também por fibra ótica e satélite, a recepção de alta fidelidade com equipamentos também digitalizados, fazem que o rádio participe plenamente da revolução das novas tecnologias e do universo multimediático. Cada vez mais emissoras colocam sua programação completa, de 24 horas, na Internet. Com um receptor pequeno, a pilhas, são captadas, via satélite, dezenas de canais com sinais multimídia." 57

Com os recursos tecnológicos atuais, a idéia de Brecht poderá, teoricamente, vir a ser plenamente cumprida. A interatividade deve ser vista como uma evolução com relação à comunicação permitida pelos meios unidirecionais e se caracteriza pela substituição da postura passiva por uma utilização ativa do meio. A configuração tecnológica dos novos meios permite o feedback imediato, simultâneo à emissão e enviado ao receptor pelo mesmo canal de daransmissão utilizado pelo emissor. Quando se fala de interatividade permitida pelos novos meios, ou de modo mais geral, pelos dispositivos informáticos, está se falando de um tipo de comunicação possível graças às potencialidades específicas de determinadas configurações tecnológicas.

$$
\text { Característica típica da }
$$

comunicação interativa é o fato de o receptor passar a desempenhar um novo papel, o de usuário, com idéia implícita de participação ativa. Sobre este fenômeno da interação podemos observar que em um contexto onde as máquinas estão cada vez mais presentes, a qualidade da interação homemmáquina será fundamental para a qualidade de vida e ainda mais 
importante será sua correta compreensão por parte do maior número possível de usuários. No início do rádio, era necessário o domínio técnico para poder produzir/utilizar equipamentostádio continua sendo um meio de conteúdos. Agora, em tempos de reconhecidas potencialidades, porém, informática e de Internet, essa exigência extremamente mal utilizado. A essência volta a estar presente. Com a interatividad@a proposta de Brecht para tomá-lo um proporcionada pela tecnologia, talvez os meio de articulação da esfera pública e ouvintes possam determinar os conteúdoso pleno desenvolvimento da sociedade, e, optar pela tecnologia possa ser uma expressão de liberdade e não uma expressão de necessidade.

De qualquer forma, passado mais de meio século desde que Bertolt Brecht discutiu o novo meio que, nos anos 20 , apenas despontava, podemos constatar que continuamos muito distantes de atingir os ideais por ele propostos. $\mathrm{O}$ jamais foi encarado com seriedade pelos estudiosos. E, ainda hoje, mais do que pensar em rádio, é preciso pensar em desenvolver o conceito de cidadania, com seus direitos e responsabilidades.

"Derepente, surgiu a possibilidade de dizer tudo a todos; mas, analisando bem, não havia nada a dizer. "'-Bertolt Brecht 